\title{
FEATURES AND PARTICULARITIES OF THE MEDICINE SUPPLY CHAIN IN ROMANIA: A COMPLEX STATISTICAL ANALYSIS
}

\author{
MANUELA ROZALIA GABOR $^{1 *}$, VICTOR ALEXANDRU GAVRILAȘ ${ }^{2}$, PETRUȚA BLAGA $^{1}$, \\ LIVIU MARIAN $^{1}$ \\ I "George Emil Palade” University of Medicine, Pharmacy, Sciences and Technology of Târgu Mureș, Romania \\ ${ }^{2}$ Technical University of Cluj-Napoca, Romania
}

*corresponding author: manuela.gabor@umfst.ro

Manuscript received: April 2019

\begin{abstract}
Pharmacy is one of the most extensively used facilities in healthcare, therefore it is important to measure its degree of satisfaction in relation with medicine distributors. The aim of this research is to analyse - using complex statistical methods the features and particularities of the relation between pharmacies and medicine distributors in two Romanian counties (Braşov and Mureş). Our results also point out a statistically significant sensitivity of Romanian pharmacies towards the discounters provided by the medicine distributors. Because the results of this research are statistically significant we can conclude that these results can be inferred at the national level and offer a real perspective for the supply chain management. Our results show that the role of medicine distributors has expanded beyond the traditional selling function and includes a strong connection to the market.
\end{abstract}

\section{Rezumat}

Farmacia este una dintre cele mai utilizate unități în domeniul sănătății, prin urmare, este important să se măsoare gradul lor de satisfacție în relația cu distribuitorii de medicamente. Scopul acestei cercetări este de a analiza - folosind metode statistice complexe - caracteristicile şi particularităţile relației dintre farmacii şi distribuitorii de medicamente din două județe din România (Braşov și Mureș). Rezultatele noastre evidențiază o sensibilitate statistic semnificativă a farmaciilor față de discounturile acordate de distribuitorii de medicamente. Deoarece rezultatele prezentei cercetări sunt semnificative statistic, putem concluziona că aceste rezultate pot fi extinse la nivel național și oferă o perspectivă reală pentru managementul lanțurilor de aprovizionare. Rezultatele noastre arată că rolul distribuitorilor de medicamente s-a extins dincolo de funcția tradițională de vânzare și include o legătură puternică cu piața.

Keywords: pharmacies, medicine distributors, inferential statistics, quantitative analysis

\section{Introduction}

The Romanian pharmaceutical market has a lot of particularities $[6,8,14]$ including the supply chain of medicine, the existing supply chain vulnerabilities impact health systems and risk consumer safety $[1,3]$ the causal relationship between operational managers of pharmacies and users [6]. Pharmaceutical's wholesalerdistributors represent a vital actor in the pharmaceutical supply chain [4], the Romanian pharmaceutical sector being one with a higher value of ratios of return on assets and return on sales [5], even during the great recession, a great number of pharmaceutical chains flourished [15], the Romanian pharmaceutical products sector was maintained on an ascending trajectory despite the financial crisis and the international level difficulties [10].

Pharmacy is one of the most extensively used facilities in healthcare [3, 13], therefore, it is important to measure its degree of satisfaction in relation with medicine distributors. Distribution network design affects the company's operating costs and customer service level [12], medicine distributors also have an important role in the pharmaceutical production chain [11]. The customer satisfaction, as an outcome of successful customer relationship management, is correlated with the efficiency of the logistics and supply chain management [14], the demand for medicines is shaped in the form of supply-induced demand [3]. Pharmacists must have a pharmaceutical care practice in accordance with patients' needs but also to have more efficient communication with them [6].

The aim of this research is to analyse - using complex statistical methods - the features and particularities of the relation between pharmacies and medicine distributors in two Romanian counties (Braşov and Mureş). We mention that this paper is only a part of a complex research of the authors [6].

\section{Materials and Methods}

For this study we have used 198 questionnaires (consisting of 14 items) completed by the pharmacists from Mureș and Braşov counties, both from hospital 
and retail, from $1^{\text {st }}$ May to $15^{\text {th }}$ July 2018. We used SPSS v17.0 soft for the complex statistical analysis, respectively: descriptive statistics (mean, median, standard deviation, minim and maxim); Pearson correlations to analyse the direction and intensity of associations between variables; Kolmogorov-Smirnov test to analyse the normal distribution of the responses; Chi square test, to test which variables differentiate according to the degree of satisfaction of pharmacists in relation with drugs distributors; $t$ Student test to test the differences between means of items scores; MannWhitney test to test which of the items differentiate between the satisfied and unsatisfied pharmacist in relation with drugs distributors. The questions were

in accordance with the principles of pharmaceutical practice regulated in the Romanian Pharmaceutical Good Practice Rules [19].

\section{Results and Discussion}

In order to analyse the central tendency of the items we applied the descriptive statistics. Data being qualitative, the results from Table I represent the values calculated based on codes of the responses of each items in the study based on the SPSS procedure, respectively each answers receive a numerical code. The legend for each numerical code of the answers is mentioned in Table I, after each items of the questionnaire.

Table I

Descriptive statistics for the items

\begin{tabular}{|c|c|c|}
\hline Questionnaire' items & $\begin{array}{l}\text { Mean } \pm \text { Std. } \\
\text { Deviation } \\
\text { (Minimum - } \\
\text { Maximum) }\end{array}$ & Median \\
\hline $\begin{array}{l}\text { C1.Are you satisfied with the collaboration of pharmacy with medicine distributors? } \\
(1-\text { very satisfied, } 2 \text { - satisfied, } 3 \text { - unsatisfied, } 4 \text {-very unsatisfied })\end{array}$ & $1.88 \pm 0.468(1-3)$ & 2.00 \\
\hline $\begin{array}{l}\text { C2. What services offered by medicine distributors could be improved? } \\
(1 \text { - their supply, } 2 \text { - offering discounts for more medicines, } 3 \text {-communication between the } \\
\text { sales department and the shipping department, } 4 \text { - payment terms that are too short, } 5 \text { - the } \\
\text { too short terms of validity of some medicines, } 6 \text { - lack of online ordering, } 7 \text { - the delivery } \\
\text { time of the medicines })\end{array}$ & $3.02 \pm 2.039(1-7)$ & 2.00 \\
\hline $\begin{array}{l}\text { C3. What discounts are given by medicine distributors? } \\
(1-1 \%-5 \%, 2-5 \%-10 \%, 3-10 \%-15 \%, 4 \text { - over } 15 \%)\end{array}$ & $1.81 \pm 0.591(1-3)$ & 2.00 \\
\hline $\begin{array}{l}\text { C4. What payment deadline are request by the medicine distributors? } \\
(1-30-60 \text { days, } 2-60-90 \text { days, } 3-90-120 \text { days, } 4 \text { - over } 120 \text { days, } 5 \text { - payment at } \\
\text { delivery })\end{array}$ & $2.18 \pm 0.841(1-4)$ & 2.00 \\
\hline $\begin{array}{l}\text { C5. What is the delivery term of the ordered products? } \\
(1-\text { few hours, } 2-12 \text { hours, } 3-24 \text { hours, } 4 \text {-more than } 24 \text { hours })\end{array}$ & $2.64 \pm 1.070(1-4)$ & 3.00 \\
\hline $\begin{array}{l}\text { C6. What is the pharmacists' discontent concerning the supply of pharmacies by medicine } \\
\text { distributors? } \\
(1 \text { - faulty supply of medicine suppliers, } 2 \text { - lack of drugs produced by suppliers but not } \\
\text { available on the market, } 3 \text { - errors and delays in the delivery of the ordered medicines, } \\
4 \text { - insufficient staff, } 5 \text { - the lack of communication within the supply department between } \\
\text { the sales department and the shipping department, } 6 \text { - the discounts are too small, } 7 \text { - the } \\
\text { payment terms are too short) }\end{array}$ & $2.68 \pm 1.633(1-7)$ & 2.00 \\
\hline $\begin{array}{l}\text { C7. What are the services supplied by medicine distributors and appreciated by the } \\
\text { pharmacists? } \\
(1-\text { prompt delivery of orders, } 2 \text {-good communication between pharmacies and medicine } \\
\text { distributors, } 3 \text { - advantageous offers, } 4 \text { - good terms of validity of products from medicine } \\
\text { suppliers, } 5 \text { - diversity of medicine supply) }\end{array}$ & $2.53 \pm 1.430(1-5)$ & 2.00 \\
\hline $\begin{array}{l}\text { C8. What are the most important criteria in a collaboration relationship with medicine } \\
\text { distributors? } \\
(1-\text { the professional training of the employees in the field, } 2 \text {-good supply of the medicine } \\
\text { distributors, } 3 \text {-payment terms, } 4 \text { - the discounts offered) }\end{array}$ & $1.99 \pm 0.896(1-4)$ & 2.00 \\
\hline $\begin{array}{l}\text { C9. How do you assess the evolution of medicine distributors? } \\
\text { (1-there will be a decrease in the number of medicine distributors at national level, } 2 \text { - the } \\
\text { services offered will be of a higher quality, } 3 \text {-only the importers will survive, } 4 \text {-will pass } \\
\text { to the electronic transmission of the orders) }\end{array}$ & $2.01 \pm 1.153(1-4)$ & 2.00 \\
\hline
\end{tabular}

Based on the descriptive statistics from Table I it can be observed that: generally, the pharmacists are satisfied with the collaboration with medicine distributors (C1); the medicine distributors must improve the communication between the sales department and the shipping department, but also we have a median value for level 2 for this item which indicate that more of fifty answers about the offering discounts for more medicines (item $\mathrm{C} 2$ ); often the medicine distributors offer $5-10 \%$ discounts (item $\mathrm{C} 3$ ), between 69 and 90 days for payment deadlines (item C4) and they deliver the medicines in 24 hours (item C5); the 
pharmacists are unsatisfied with the errors and the delays in the delivery of the ordered medicines and more of fifty percent (the median value) with lack of drugs produced by suppliers, but not available on the market (item C6); the most appreciated service offer by the suppliers is advantageous offers and more than fifty percent, the median value also indicate good communication between pharmacies and medicine distributors (item C7); the most important criteria indicated by the pharmacist, in relation with medicine distributors is the good supply of the medicine distributors (item C8); the pharmacists appreciate that in the future the offered services will be of a higher quality (item C9).

Because there were differences in the first item of the questionnaire, referring to the satisfied degree of pharmacists in relation with medicine distributors, and there were various opinions and appreciations to the other questions in the questionnaire, we applied the nonparametric statistic to deepen the interpretation of the data.

Therefore, Chi square test was applied with the null hypothesis: $\mathrm{H}_{0}=$ There are no statistically significant differences depending on the degree of satisfaction of the pharmacies regarding the relation with medicine distributors, related to all the other aspects of the study. The results indicate only for four items from total a statistic significance of p-value (Asymp. Sig) $<0.05$. For acceptance or rejection of the null hypothesis we used the comparison of the calculated value of statistic $\chi^{2}$ with theoretical distribution of Chi square values. For higher calculated value than theoretically, the null hypothesis was rejected, concluding that there are differences depending on the degree of satisfaction with that aspect. The results of Chi square bivariate test indicate the following items with $\mathrm{p}$ value < 0.05: C4. "What payment deadline are request by the medicine distributors?" $(\mathrm{p}=0.037)$; $\mathrm{C} 5$. "What is the delivery term of the ordered products?" ( $p=$ 0.011); C7. "What are the services supplied by medicine distributors and appreciated by the pharmacists?" ( $p=$ 0.040); and C8. "What are the most important criteria in a collaboration relationship with medicine distributors?" $(\mathrm{p}=0.018)$.

The results for this analysis indicate that there are significant statistical differences of the respondents depending on the degree of satisfaction with the following aspects: the payment deadline requested by the medicine distributors (item $\mathrm{C} 4$ ), the services supplied by them appreciated by the pharmacists (item C7) and the most important criteria in relationship with medicine distributors (item C8). Regarding the delivery term of the ordered products, there are no differences among pharmacist opinions (item C5). To test if there are significant statistical differences between the score averaged by the answers of each item, the Student t test was applied.
Because for each item of the study the p-value (Sig. 2-tailed) $=0.000$ (statistically significant for $100 \%$ of sample) it is indicated that the scores' averages of the answers are statistically significant for all 9 items of the study (from $\mathrm{C} 1$ to $\mathrm{C} 9$ ), respectively: the degree of satisfaction for collaboration of pharmacy with medicine distributors, the services offered by the medicine distributors that could be improved, the discounts, the payment deadline, the delivery term for ordered products, the pharmacists' discontent, the services appreciated by the pharmacists, criteria for a good collaboration with distributors, the assessment of medicine distributors' evolution. These aspects show that the results from our research can be inferred at the national level and the research sample is representative. To establish if there are correlations between the variables of the study and to analyse both the direction and intensity of these correlations, we applied Pearson correlations analysis. The results of the parametric correlation analysis indicate that the items $\mathrm{C} 1$. "Are you satisfied with the collaboration of pharmacy with medicine distributors?" and C6. "What is the pharmacists' discontent concerning the supply of pharmacies by medicine distributors?" have not statistical significance with any other items from the research study.

From the above mention analysis it can be noticed that there are positive (direct) and also negative (reverse) ones, but low in intensity (all the statistically significant coefficients are under 0.400 value), both statistically significant, but low in intensity (Pearson coefficients $\leq$ 0.300). Regarding the negative (reverse) correlations, we have noticed that: the deadline for payments increases, the deadline for medicine delivery decreases (correlation between items C4 and C5 from Table I) and also if the deadline delivery for medicine decreases (from over 24 hours to only a few hours), then the more important criteria for the relationship pharmacist medicine suppliers increase to the deadlines for payments and offered discounts (correlation between items C5 and C8 from Table I). Regarding the positive (direct) correlations, the results indicate that: the increased number of services that can be improved (item C2) is direct correlated with: increasing of accorded discounts (item C3), increasing of payment deadlines (item C4) and increasing of delivery time (item C5); the increasing of the discounters accorded by the medicine suppliers (item C3) are correlated with the increasing payment deadlines (item C4), increasing of appreciations services offered by the medicine suppliers (item C7) and increasing of the most important criteria in relationship pharmacists - medicine suppliers, respectively, discounts and payment deadlines (item $\mathrm{C} 8$ ); the increasing of payment deadlines (item C4) is followed by the increasing of the most important criteria in relationship pharmacists - medicine suppliers, respectively, discounts and payment deadlines (item $\mathrm{C} 8$ ); the increasing of delivery time (item C5) is 
correlated with the increasing of future evolution of the medicine suppliers in Romania (item C9); and the increasing of appreciation services offered by the medicine suppliers (item C7) is correlated with the increasing of the most important criteria in relationship pharmacists - medicine suppliers, respectively, discount and payment deadlines (item C8).

To test if the answers of each item are normal distributed (Gauss curve) we applied the One Sample KolmogorovSmirnov $Z$ test. The results show that for all 9 items from the Table I the distribution is normal, p-value = 0.000 (Asymp. Sig. (2-tailed)) and this aspect ensures the statistical inference of the research results in general population, namely at national level.

In order to test for which of the 9 items (C1 - C9) the degree of satisfaction of the pharmacies in the study is different, we divided the 198 pharmacies into two groups (152 respondents were satisfied and 11 respondents were dissatisfied) and applied the Mann-Whitney $U$ test for two different samples (independent samples) to test the statistically significance of these differences.

According to the results of Mann-Whitney U test, it is shown that the degree of satisfaction or dissatisfaction is sensitive to discounts provided by the medicine distributors (item C3 from Table I) for $97.3 \%$ of the sample and into significant proportion (but less than $95 \%$ of the accepted statistical significance) of $91.7 \%$ for variable "payment terms require by the medicine distributors" (item C4 from Table I). All the rest of the variables indicate no statistical significance sensitiveness. A good relation between pharmacies - medicine distributors is very important for the healthcare because their mission is not just about delivery, but to ensure the access to the right medicine to all patients at the right time, safely and efficiently [2, 4].

The results of our research present an important particularity of the Romanian pharmaceutical market: from the nine variables in the study, only two $(\mathrm{C} 1$. "Are you satisfied with the collaboration of pharmacy with medicine distributors?" and C6 "What are the pharmacists' discontent concerning the supply of pharmacies by medicine distributors?') weren't correlated with any other variables, even the supply systems in low-income and middle-income countries remain exposed to the risk of poor-quality medicines [18]. Our research results are also important if we take into consideration the aspect of the competition from distributors of generic medicines and consumers behaviour [7], the Romanian pharmaceutical market remains a booming industry, being full of opportunities and attractiveness for foreign suppliers [9].

Because the variables $\mathrm{C} 3$. "What the discounts are given by medicine distributors?" and C4. "What payment deadline are request by the medicine distributors?" are the variables which make the difference regarding the satisfaction level of this relationship, our results confirm the international ones, namely that the procuring and purchasing requested items in a timely manner are the two most important issues for supply chain stockholders [17].

Our results also point out a statistically significant sensitivity of Romanian pharmacies to the discounters provided by the medicine distributors, this aspect being important because of maximum limit prices (according to the CaNamed report) for suppliers, distributors and drugstores [8].

Because the results of this research are statistically significant (p-value < 0.05) [16], even the sample of the study was made up of pharmacies only for two Romanian county, Mureș and Brașov, we can conclude that these results can be inferred at the national level according to the normal distribution of KolmogorovSmirnov $Z$ test results.

\section{Conclusions}

We consider that the present results fill a gap in the national and international literature regarding the relations between pharmacists and medicine distributors, highlight the features and particularities of the Romanian supply chain and offer a real perspective for supply chain management. Romania has been and will remain a long-term challenging business and an attractive market for foreign pharma suppliers. Our results show that the role of medicine distributors has expanded beyond the traditional selling function and includes a strong connection to the market.

\section{Conflict of interest}

The authors declare no conflict of interest.

\section{References}

1. Ciulu R, The strategic role of sales professionals in the pharmaceutical industry. GEBA, 2011; 4: 449-453.

2. Ciolan DF, Andrei CA, Mirică A, Toma IE, Drăgănescu D, Rădulescu FS, Internships in pharmaceutical students' development. Farmacia, 2020; 68(1): 176-184.

3. Duong MH, Moles Rebekah J, Chaar B, Chen TF, Stakeholder roles in facilitating access to essential medicines. Res Social Adm Pharm., 2019; 15(3): 260266.

4. Essajide L, Rachidi A, Fikri M, Combining SCOR and BPMN to support supply chain decision-making of the pharmaceutical wholesaler-distributors. ICLOM (GOL.), 2018; 1-10.

5. Gaban L, Masca E, Morar ID, Fatacean G, Moscviciov A, Statistical analysis of performance in SMEs. $C$ SCI., 2018; 115(8): 1543-1549.

6. Gabor MR, Blaga P, Gavrilaș VA, Perception of promoting activity in Romanian supply chain of chemical substances. A complex statistical analysis. Rev Chim (Bucharest), 2019; 70(12): 4477-4481.

7. Gauld N, Bryant L, Emmerton L, Kelly F, Kurosawa $\mathrm{N}$, Buetow S, Why does increasing public access to medicines differ between countries? Qualitative comparison of nine countries. J Health Serv Res Policy, 2015; 20(4): 231-239. 
8. Gavrilas VA, Marian LO, Al-Akel K, Services offered by the medicine suppliers from the pharmacist's point of view. RMEE, 2018; 6: 230-237.

9. Giurea AM, Lolea IC, Analytical review of the pharmaceutical industry in Romania. Strategica, 2017; 5: 537-549.

10. Kagitci M, Nichita ME, Vulpoi M, Paunescu M, A survey of evolution of profitability indicators of pharmacy entities listed on Bucharest stock exchange before and during the global financial crisis. AMIS, 2012; 7: 1040-1048.

11. Kralik LS, Martins VLM, De Paula IC, Improvement in process of buying a distributor of drugs: Cluster analysis and forecasting demand for new products. Espacios, 2013; 34(12): 6-19, (available in Spanish).

12. Liu $M, X u X, Z$ Zhang D, Integrated optimization model for distribution network design: a case study of the clothing industry. Int T Oper Res., 2019; 26(4): 12691292.

13. Pokhariya U, Mathur P, Review on: inventory management. Indo Amer J Pharm Sci., 2018; 5(4): 3124-3131.

14. Prejmerean MC, Vasilache S, A LSCM approach to the Romanian pharmaceuticals market. Amfiteatru Economic, 2008; 10(24): 166-176.
15. Pană $\mathrm{M}$, Crăciun $\mathrm{P}$, Nicolae $\mathrm{C}$, Tăerel $\mathrm{AE}$, Lupuliasa $\mathrm{D}$, The cardiovascular market in Romania during 1998 2017 period - analysis and evolution. Farmacia, 2019; 67(5): 922-930.

16. Rojas F, Coluccio G, Vega J, Relationships between supply performance of pharmacies in Chile and their quality of customer service. Int J Pharmacol Health, 2018; 12(4): 433-446.

17. Safaei AS, Heidarpoor F, Paydar MM, Group purchasing organization design: a clustering approach. Comput Appl Math., 2018; 37(2): 2065-2093

18. van Assche K, Giralt AN, Caudron JM, Schiavetti B, Pouget C, Tsoumanis A, Meessen B, Ravinetto R, Pharmaceutical quality assurance of local private distributors: a secondary analysis in 13 low-income and middle-income countries. BMJ Global Health, 2018; 3(3): 1-10.

19. *** Order no. $75 / 2010$ for the approval of good pharmacy practices rules. Official Journal of Romania ( $1^{\text {st }}$ part). Ministry of Health, 2010; 91, (available in Romanian). 